\title{
Effects of Different Concentrations of Organic Waste on Selected Traits of Individuals Capsicum Chinense Jacq.
}

\author{
Francisco Orlando Holanda Costa Filho ${ }^{1}$, Jefania Sousa Braga Amorim ${ }^{1}$, Magnum de Sousa Pereira ${ }^{1}$, Francisca \\ Edineide Lima Barbosa ${ }^{1}$, Rifandreo Monteiro Barbosa ${ }^{1}$, Roberto Albuquerque Pontes Filho ${ }^{1}$ \& Franklin Aragão \\ Gondim ${ }^{1}$ \\ ${ }^{1}$ Instituto Federal de Educação, Ciência e Tecnologia do Ceará (IFCE), Maracanaú Campus, Brazil \\ Correspondence: Franklin Aragão Gondim, IFCE, Maracanaú Campus, Brazil. E-mail: aragaofg@yahoo.com.br
}

Received: October 26, 2016

Accepted: December 20, $2016 \quad$ Online Published: February 7, 2017

doi:10.5539/jps.v6n1p76

URL: http://dx.doi.org/10.5539/jps.v6n1p76

\begin{abstract}
At present, excessive waste production makes it necessary to carry out research aimed to minimize the problems arising from waste generation and inadequate disposal. In this sense, this study aimed to analyze plant growth, fruit production, antioxidative enzyme activities and organic solute contents in fruits of Capsicum chinense Jacq. plants (BRS Moema cultivar) growing in substrates with different concentrations of municipal organic solid waste (MW) or shrimp waste (SW) under greenhouse conditions. A completely randomized design was used with seven treatments (control; MW at 50, 100 and 200\% of recommendation; and SW also at 50, 100 and 200\%) and five replications. The MW and SW were mixed with the soil. When plants already had fruits, 122 days after sowing (DAS), shoot height, stem diameter and number of leaves were determined, and 134 DAS, the visibly ripe fruits were collected and stored at $-20^{\circ} \mathrm{C}$ for subsequent biochemical analysis. The $\mathrm{MW}$ and $\mathrm{SW}$ provided a linear increase in the parameters of shoot height, stem diameter and number of leaves. The numbers of fruits in the treatments were quite variable, but it can be concluded that the MW 200 and SW 100 treatments provided higher fruit production. The best results for the activities of catalase (CAT), ascorbate peroxidase (APX) and guaiacol peroxidase (GPX) in the fruits occurred in the MW 100 and SW 200 treatments. Both provided an increase in CAT and reductions in APX and GPX, which can contribute to greater postharvest life of $C$. chinense Jacq. fruits. In relation to soluble protein and carbohydrate contents, the MW 100 and SW 100 treatments did not contribute to their increase; in the other residue concentrations, the results were variable. However, considering all parameters analysed in this study, the most suitable treatments would be MW 100 and SW 100. Therefore, the results demonstrate the susceptibility of using substrates with $\mathrm{MW}$ and $\mathrm{SW}$ in the cultivation of $C$. chinense Jacq. plants.
\end{abstract}

Keywords: Capsicum chinense Jacq., organic waste, antioxidative enzymes, organic solutes

\section{Introduction}

Excessive waste production and the difficulty to dispose of it properly have become big problems today that threaten environmental quality. In many cases, solid waste is simply deposited on the ground, in open places, without any control. This inadequate form of waste disposal causes numerous problems of an environmental and social nature that can be minimized through reuse and/or recycling of waste (Jacobi \& Besen, 2011).

Organic solid waste has a high potential for use in agriculture. These residues, which are rich in organic matter and nutrients, can be used in the composition of agricultural substrates used in plant cultivation, improving the quality of the substrates and contributing to better plant growth (Abreu-Júnior, Boaretto, Muraoka, \& Kiehl, 2005).

The potential use of organic waste for agriculture can be one of the solutions for the proper disposal of waste, in view of Brazilian Law 12.305 of Aug. 2, 2010, which established the National Policy on Solid Waste that aims to increase recycling and reuse of waste. Considering that more than $50 \%$ of Brazilian municipal solid waste consists of organic matter (Ministério do Meio Ambiente [MMA], 2012), the recycling of these residues would reduce significantly the volume to be disposed in the soil, therefore reducing pollution resulting from the disposal in dumps while providing increased lifespan of the landfills (Worrell \& Vesilind, 2012).

In addition, these residues when applied to the soil can provide improvements in its physical, chemical and 
biological characteristics, which also may result in better plant development (Bot \& Benites, 2005). At the same time, with the use of these residues in agriculture, there would be a decrease in the use of chemical fertilizers, reducing manuring costs and impacts caused by the use of fertilizers (Abreu-Júnior et al., 2005).

However, to have success in the use of these organic residues in the improvement of plant growth, it is extremely important to carry out studies to establish appropriate concentrations to be used, because a condition of deficiency or excess nutrients present in organic matter can compromise plant development (Maathuis \& Diatloff, 2013). Additionally, when exposed to adverse conditions, such as drought, high and low temperatures, pathogen attack and deficient or excess nutrients, plants may suffer secondarily to oxidative stress (Ramakrishna \& Ravishankar, 2011). In these situations, there is an imbalance between the production of reactive oxygen species (ROS) and the action capacity of the antioxidant defense system, resulting in an accumulation of ROS, which are substances generated by normal cellular metabolism of aerobic organisms. When present in excess, however, ROS can impair the metabolism of plants by harmful action to various cellular components (Hawlliwell \& Gutteridge, 2007; Møller, Jensen, \& Hansson, 2007; Noctor \& Foyer, 1998).

The plant used in this research, Capsicum chinense Jacq. (BRS Moema), is largely grown in Brazil, has a height between 45 and $76 \mathrm{~cm}$ and produces pepper fruits ranging from 1 to $12 \mathrm{~cm}$ in length, which have variable shapes and colors in addition to high nutritional value and antioxidant potential (Smith \& Heiser, 1957; P. Vaishnava \& D. W. Wang, 2003).

To provide greater relevance, this study sought to use municipal organic solid waste (MW) and also shrimp waste (SW) in the composition of substrates. Shrimp farming is an activity that has great socioeconomic importance in Brazil, especially in the northeast region (Rocha, 2011). However, this activity is responsible for generating large quantities of waste from processing the shrimp. Nevertheless, there is no research in the literature that addresses the use of shrimp waste in substrate composition and, consequently, in improving growth of $C$. chinense Jacq. Therefore, the objective of this study was to evaluate the influence of substrates with different concentrations of MW and SW on plant growth, productivity of fruits, activities of antioxidative enzymes and organic solute contents of the fruits of $C$. chinense Jacq. growing under greenhouse conditions. The hypothesis of this study is that the use of substrates with MW and SW may provide greater plant growth, productivity of fruits and antioxidant defense system than the control treatment, which does not have MW and SW.

\section{Method}

\subsection{The Experiment Design}

The experiment was carried out under greenhouse conditions at the Laboratório Terra of the Instituto Federal de Educação, Ciência e Tecnologia do Ceará (IFCE), Maracanaú campus, located in Maracanaú, Ceará, Brazil. During the day, the average temperature inside the greenhouse was $33.3{ }^{\circ} \mathrm{C}$ and relative humidity $54 \%$. The experiment was carried out between November 2013 and April 2014.

To set up the experiment, 16-L plastic buckets with holes drilled in the bottom ends for drainage of excess water were used. Irrigation conducted during the experiment was performed manually and aimed at maintaining the water content of the soil near field capacity. The seeds for the production of seedlings were obtained commercially and sown in Styrofoam trays with 128 cells containing vermiculite and worm humus as a substrate in a volumetric ratio of 2:1. After germination and early seedling growth, 49 days after sowing (DAS), plants were transplanted to the plastic buckets containing different treatments described in following section (2.2 Definition of the waste concentrations for the composition of the substrates).

The soil used in the experiment was obtained from subsoil excavation in an area close to the IFCE Maracanaú campus. To characterize the soil used in the preparation of substrates, samples were separated and sent to the Laboratório de Solo/Água of the Universidade Federal do Ceará (UFC), which carried out the necessary analyses (Table 1). 
Table 1. Chemical analysis of the soil used in the composition of the substrates for cultivation of Capsicum chinense Jacq. Plants

\begin{tabular}{|c|c|c|c|c|c|c|c|c|c|c|}
\hline \multicolumn{3}{|c|}{$\mathrm{g} / \mathrm{kg}$} & \multirow[b]{2}{*}{$\mathrm{C} / \mathrm{N}$} & \multicolumn{5}{|c|}{$\mathrm{mg} / \mathrm{kg}$} & \multirow{2}{*}{$\begin{array}{c}\mathrm{H}_{2} \mathrm{O} \\
\mathrm{pH}\end{array}$} & \multirow{2}{*}{$\begin{array}{l}\mathrm{dS} / \mathrm{m} \\
\mathrm{E} . \mathrm{C}\end{array}$} \\
\hline O.M & $\mathrm{C}$ & $\mathrm{N}$ & & $\begin{array}{l}\text { Assimilable } \\
\text { phosphorus }\end{array}$ & $\mathrm{Fe}$ & $\mathrm{Cu}$ & $\mathrm{Zn}$ & $\mathrm{Mn}$ & & \\
\hline \multirow[t]{2}{*}{6.93} & 4.02 & 0.39 & 10 & 2 & 17.9 & 0.3 & 0.9 & 3.4 & 5.2 & 0.15 \\
\hline & & & $\mathrm{cmol}_{\mathrm{C}} / \mathrm{kg}$ & & & S R & $C F C$ & & $\%$ & \\
\hline $\mathrm{Ca}^{2+}$ & $\mathrm{Mg}^{2+}$ & $\mathrm{Na}^{+}$ & $\mathrm{K}^{+}$ & $\mathrm{Al}^{3+}$ & $\mathrm{H}^{+}+\mathrm{Al}^{3+}$ & S.D & C.E.C & B.S & $\mathrm{M}$ & E.S.P \\
\hline 0.50 & 0.30 & 0.07 & 0.14 & 0.85 & 1.98 & 1.0 & 3.0 & 33 & 46 & 2 \\
\hline
\end{tabular}

Note. O.M = organic matter; E.C = electrical conductivity; S.B = sum of bases; C.E.C = cation exchange capacity; B.S = base saturation percentage; $\mathrm{M}=$ aluminum saturation percentage; $\mathrm{E} . \mathrm{S} . \mathrm{P}=$ exchangeable sodium percentage.

The SW was obtained from an effluent treatment plant in the shrimp processing industry located in Aracati, Ceará, Brazil. During the treatment of shrimp processing waste, sludge is generated as a byproduct, which is put into a drying bed and later sent to a landfill. Part of this dry sludge was collected, analyzed and used in the experiment as shrimp waste (Table 2).

Table 2. Chemical analysis of the shrimp waste used in the composition of the substrates for cultivation of Capsicum chinense Jacq. plants.

\begin{tabular}{cccccccccccc}
\hline \multicolumn{10}{c}{$\mathrm{g} / \mathrm{kg}$} & & \multicolumn{4}{c}{$\mathrm{mg} / \mathrm{kg}$} \\
\hline $\mathrm{N}$ & $\mathrm{P}$ & $\mathrm{P}_{2} \mathrm{O}_{5}$ & $\mathrm{~K}$ & $\mathrm{~K}_{2} \mathrm{O}$ & $\mathrm{Ca}$ & $\mathrm{Mg}$ & & $\mathrm{Fe}$ & $\mathrm{Cu}$ & $\mathrm{Zn}$ & $\mathrm{Mn}$ \\
\hline 38.2 & 8.5 & 19.5 & 2.5 & 3.1 & 8.3 & 4.3 & & 5713.7 & 1297.9 & 1893.4 & 134.6 \\
\hline
\end{tabular}

The MW was obtained from municipal waste processing performed by the company Kermais Ambiental \& Lubbad Ambiental. The process known as EcoKer involves weighing the MW; separating all recyclable, inert and ferrous metals; shredding the residues for volume reduction and homogenization; separating non-ferrous metals; and ending the process, which lasts only $4 \mathrm{~h}$ in total, the MW is added in a mixer along with a cleaning agent and quicklime, resulting in the organic fertilizer used in this study and a fuel derived from waste. The results of the MW analysis are shown in Table 3.

Table 3. Chemical analysis of the municipal organic solid waste used in the composition of the substrates for cultivation of Capsicum chinense Jacq. plants.

\begin{tabular}{|c|c|c|c|c|c|c|c|c|c|c|}
\hline \multicolumn{7}{|c|}{$\mathrm{g} / \mathrm{kg}$} & \multicolumn{4}{|c|}{$\mathrm{mg} / \mathrm{kg}$} \\
\hline $\mathrm{N}$ & $\mathrm{P}$ & $\mathrm{P}_{2} \mathrm{O}_{5}$ & $\mathrm{~K}$ & $\mathrm{~K}_{2} \mathrm{O}$ & $\mathrm{Ca}$ & $\mathrm{Mg}$ & $\mathrm{Fe}$ & $\mathrm{Cu}$ & $\mathrm{Zn}$ & $\mathrm{Mn}$ \\
\hline 3.4 & 0.9 & 2.1 & 2.5 & 3.1 & 185.9 & 9.1 & 3471.8 & 9.7 & 152.7 & 66.5 \\
\hline
\end{tabular}

\subsection{Definition of the Waste Concentrations for the Composition of the Substrates}

The concentrations of the solid waste used in the composition of the different substrates were defined according to the recommendation suggested by the Brazilian Agricultural Research Corporation [EMBRAPA] (2007) of 60 $\mathrm{kg}$ of nitrogen $\mathrm{ha}^{-1}$ in the cultivation of pepper and considering the amounts of nitrogen present in the compositions of the soil $\left(0.39 \mathrm{~g} \mathrm{~kg}^{-1}\right)$ and residues (SW: $38.2 \mathrm{~g} \mathrm{~kg}^{-1}$; MW: $3.4 \mathrm{~g} \mathrm{~kg}^{-1}$ ) (Tables 1, 2 and 3). Treatments were tested using concentrations calculated for each residue as recommended by EMBRAPA (100\%), treatments using half $(50 \%)$ and twice $(200 \%)$ the concentrations of nitrogen recommended for each residue. The residues were thoroughly mixed with soil to form the different substrates, which were manually added to the plastic buckets. The substrate used as the control treatment was composed of only soil.

\subsection{The Studied Taxon}


The plant used in this study, $C$. chinense Jacq., is originally from Central and South America and largely grown in Brazil, has a height between 45 and $76 \mathrm{~cm}$ and produces pepper fruits ranging from 1 to $12 \mathrm{~cm}$ in length, which have variable shapes and colors (Smith \& Heiser, 1957). Moreover, its fruits have high nutritional value and antioxidant potential (P. Vaishnava \& D. W. Wang, 2003). The cultivar used in this research was the BRS Moema (RNC 22493), which has high productivity and is sensitive to low temperatures (Amaro, 2012).

\subsection{Plant Growth Evaluations}

When the plants already had fruits, 122 DAS, plant growth evaluations were performed. The following determinations were carried out: shoot height, stem diameter and number of leaves. The shoot height evaluations were performed with the aid of a ruler graduated in centimeters, considering the height of the base of the plant (substrate surface) to the end of the farthest leaf. The stem diameter, measured near the substrate surface, was evaluated with the aid of a digital caliper, and the number of leaves was counted manually.

When the fruits were visibly mature (dark red coloration), 134 DAS, harvest was carried out manually and selectively. At the end of harvest, the fruits were stored at $-20{ }^{\circ} \mathrm{C}$ for subsequent biochemical analysis.

\subsection{Obtaining Enzymatic Extracts for Biochemical Analysis}

The activities of the antioxidant enzymes catalase (CAT), ascorbate peroxidase (APX) and guaiacol peroxidase (GPX) in pepper fruits were determined. Thus, enzymatic extracts were prepared by maceration of $1 \mathrm{~g}$ of pepper seeds in $4 \mathrm{~mL}$ of potassium phosphate buffer at $100 \mathrm{mM}$, containing $0.1 \mathrm{mM}$ ethylenediaminetetraacetic acid (EDTA) (pH 7.0) at $4{ }^{\circ} \mathrm{C}$. For APX activity, the extract was added to ascorbate at a concentration of $2 \mathrm{mM}$. The homogenate was then filtered through nylon cloth, transferred to Eppendorf tubes and centrifuged at 12,000 x $\mathrm{g}$ for 15 min at $4{ }^{\circ} \mathrm{C}$, and the supernatant (enzymatic extracts) was removed.

\subsection{Enzymatic Activity in Fruits of Capsicum Chinense Jacq.}

The activities of the antioxidant enzymes CAT, APX and GPX were determined. The CAT activity was determined according to the method of Havir and McHale (1987) by the decrease in absorbance at $240 \mathrm{~nm}$ due to consumption of hydrogen peroxide; the GPX activity according to the method of Kar and Mishra (1976), with the reaction accompanied by the increase in absorbance at $470 \mathrm{~nm}$ due to the formation of tetraguaiacol; and the APX activity according to the method of Nakano and Asada (1981), with the oxidation of ascorbate measured by the decrease in absorbance at $290 \mathrm{~nm}$. The CAT, APX and GPX enzyme activities were expressed in micromoles of hydrogen peroxide per minute per gram of fresh matter (FM). Each extract was measured in duplicate.

\subsection{Determination of the Soluble Protein and Carbohydrate Contents in the Fruits}

The soluble protein contents were determined according to the method described by Bradford (1976). The soluble protein standard curve used was formed from a standard solution of bovine serum albumin. The protein concentration was expressed in milligrams of protein per gram of FM.

The soluble carbohydrate contents were determined according to the method of Dubois, Gilles, Hamilton, Rebers and Smith (1956). The standard curve of carbohydrates used was formed from the standard solution of anhydrous glucose. The concentration of carbohydrates was expressed in micromoles of carbohydrates per gram of FM.

\subsection{The Statistical Analyses}

A completely randomized design was used with seven treatments (control; MW at 50, 100 and 200\% of recommendation; and SW at 50,100 and 200\%) and five replications. The data were analyzed using a one-way analysis of variance (ANOVA). The means were compared through Tukey's test $(P \leq 0.05)$.

\section{Results}

\subsection{Plant Growth and Number of the Fruits}

The results of the effects of the MW and SW on C. chinense Jacq. growth are shown in Figure 1. In general, the two residues promoted an increase in plant growth in the parameters analyzed in relation to the control treatment.

In relation to shoot height (Figure 1a), it was verified that the plants grown in the presence of MW in the substrate showed higher values than those found in substrates with the control treatment. It was also observed that the MW 200 treatment was the highest and was 67\% higher than the control. Plants growing in substrates containing SW showed similar growth. SW 200 was the highest and was $94 \%$ and $16 \%$ higher than the control and MW 200 treatments, respectively.

The root collar diameter (Figure 1b) showed behavior similar to that of plant height (Figure 1a). It was observed that the MW 200 treatment exhibited the highest value among the treatments containing MW, being 32\% higher 
than the control. For the treatments with SW, the behavior was similar. SW 200 exhibited the highest value, being $85 \%$ and $39 \%$ higher than the control and MW 200 treatments, respectively.

For the number of leaves parameter (Figure 1c), it was also verified that MW 200 exhibited the highest value among the treatments containing MW, being 129\% higher than the control. For the substrates containing SW, it was observed that there was no difference in the SW 50 concentration compared to the control treatment. However, SW 100 and SW 200 differed from the control, with SW 200 being the highest value $-231 \%$ and $44 \%$ higher than the control and MW 200 treatments, respectively.

In relation to the numbers of fruits obtained, the values in the treatments were quite variable (Figure 1d). However, the MW 200 treatment followed the same trend that had been shown in relation to plant growth, being higher than the other treatments with MW and being $215 \%$ higher than the control. In relation to the SW treatments, there was not the same trend. The number of fruits in SW 200 did not differ from that of the control. The highest values occurred in the SW 100 treatment, which were 284\% higher than those of the control.

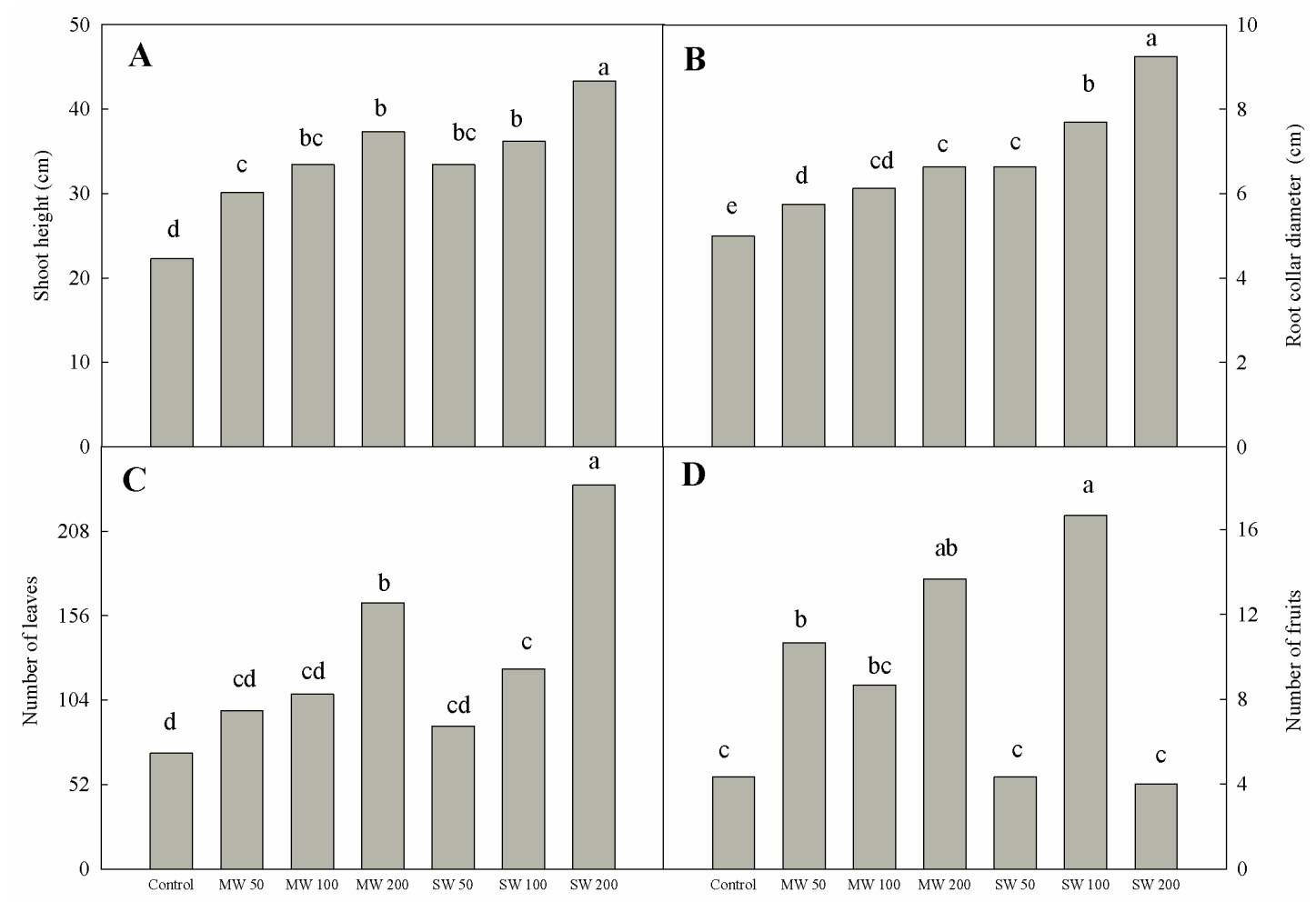

Figure 1. Shoot height (a), root collar diameter (b) and number of leaves (c) of Capsicum chinense Jacq. plants at 122 days after sowing under greenhouse conditions as well as number of fruits/plant (d) at 134 days after sowing. Plants were grown on substrates containing only soil (control), municipal organic solid waste (MW) (50, 100 or

$200 \%$ of the fertilizer recommendation) or shrimp waste (SW) (50,100 or $200 \%$ of the fertilizer recommendation). Bars represent the mean values of five replications. Values followed by the same letters are not statistically different according to Tukey's test $(P \leq 0.05)$

\subsection{Enzymatic Activity}

Figure 2 shows the CAT, APX and GPX enzyme activities in the fruits of $C$. chinense Jacq. plants growing in substrates containing different concentrations of MW and SW.

As shown in Figure 2a, the highest values for CAT activity in substrates containing MW occurred in the MW 50 and MW 100 treatments, with no difference between these treatments. The average values of MW 50 and MW 100 were 169\% higher than those of the control. The results of the MW 200 treatment did not differ in relation to those of the control. In relation to the substrates containing SW, an increase in CAT activity was observed as the concentrations of this residue increased in the substrate. The SW 50 and control treatments did not differ. However, the SW 100 and SW 200 treatments increased by 57\% and 192\%, respectively, compared to the control. Thus, the highest values of CAT activity occurred in the MW 50, MW 100 and SW 200 treatments, which did not differ 
among themselves.

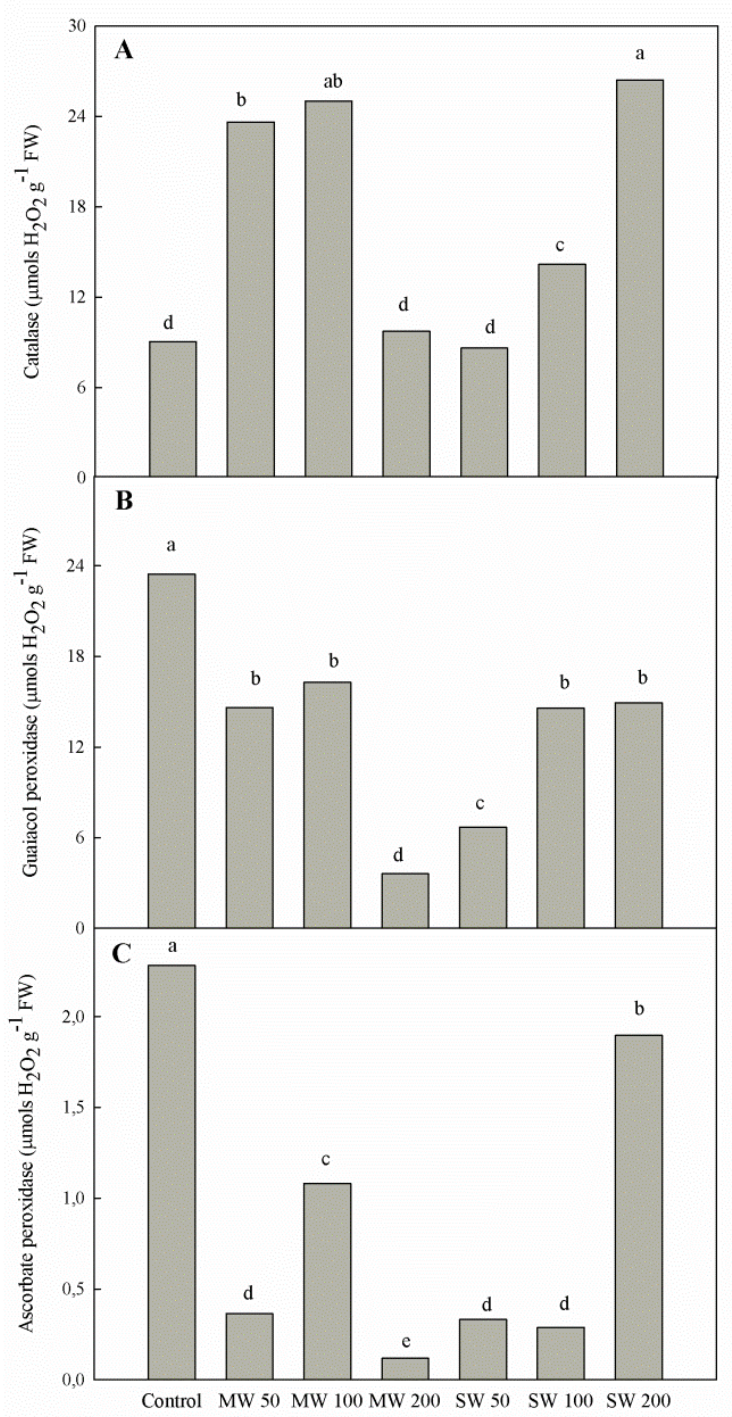

Figure 2. Activities of catalase (A), guaiacol peroxidase (B) and ascorbate peroxidase (C) in fruits of Capsicum chinense Jacq. plants at 134 days after sowing under greenhouse conditions. Plants were grown on substrates containing only soil (control), municipal organic solid waste (MW) (50, 100 or $200 \%$ of the fertilizer recommendation) or shrimp waste (SW) (50, 100 or $200 \%$ of the fertilizer recommendation). Bars represent the mean values of five replications. Values followed by the same letters are not statistically different according to Tukey's test $(P \leq 0.05)$

In Figure 2b, it was observed that the highest value of GPX activity occurred in the control treatment. In relation to the substrates containing MW, the reduction compared to the control treatment was more accentuated in MW 200, being 547\% lower. In the substrates containing SW, the reduction was lower in the SW 100 and SW 200 treatments, which did not differ among themselves. The average value of GPX of these two treatments was $58 \%$ lower than that of the control.

In relation to APX activity (Figure 2c), the control treatment was again higher compared to other treatments, and, among the MW treatments, MW 200 showed a greater reduction, being 18 times lower than the control. In relation to the substrates containing SW, SW 200 was the closest treatment compared to the control, being $20 \%$ lower.

At high concentrations of MW (MW 200), there was a decrease in the activity of the enzymes (CAT, GPX and 
APX) to values similar to or below those of the control. However, the greatest results occurred in the treatment that used the fertilizer recommendation (MW 100). In relation to the SW treatments, linearity in the results was observed such that the activities of the enzymes were higher in treatments with higher concentrations.

\subsection{Organic Solutes}

Figure 3 shows the effects of different concentrations of MW and SW on the soluble protein and carbohydrate contents in fruits of $C$. chinense Jacq. plants.

There was no difference in soluble protein content (Figure 3a) between the control and MW 100 treatments. However, the MW 50 and MW 200 treatments were 63\% and 342\% lower than the control, respectively. In relation to the treatments containing SW, there was an increase of soluble protein contents with an increase in concentrations of the residues in the substrates. The SW 50 and SW 100 treatments were $175 \%$ and $29 \%$ lower than the control, respectively. The SW 200 treatment showed the highest soluble protein content in relation to all the treatments used, being $26 \%$ higher than the control.

In the treatments with MW, the soluble carbohydrate contents (Figure 3b) exhibited a behavior similar to that of the soluble protein contents. The MW 100 treatment did not differ from the control, and the MW 50 and MW 200 treatments were $140 \%$ and $503 \%$ lower than the control, respectively. In the substrates with SW, the SW 50 and SW 100 treatments did not differ and were, on average, 82\% lower than the control. The SW 200 treatment did not differ from the control.

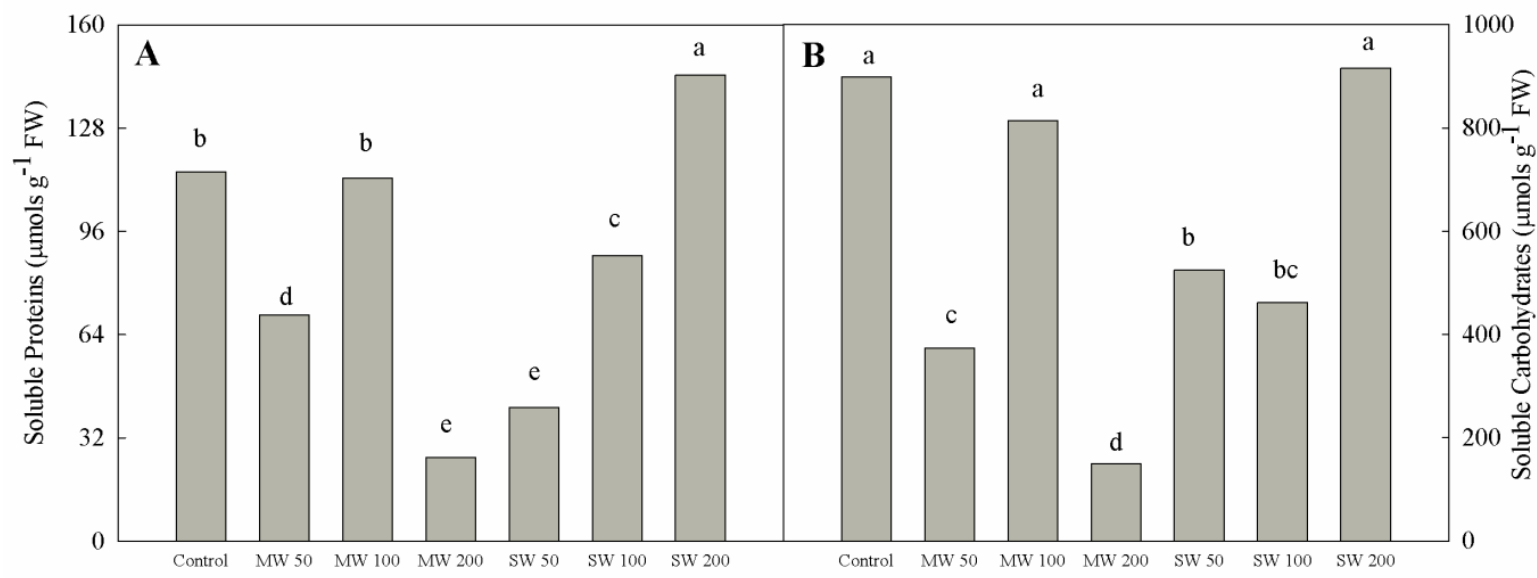

Figure 3. Contents of soluble proteins (a) and soluble carbohydrates (b) in fruits of Capsicum chinense Jacq. plants at 134 days after sowing under greenhouse conditions. Plants were grown on substrates containing only soil (control), municipal organic solid waste (MW) (50,100 or 200\% of the fertilizer recommendation) or shrimp waste (SW) (50,100 or $200 \%$ of the fertilizer recommendation). Bars represent the mean values of five replications. Values followed by the same letters are not statistically different according to Tukey's test $(P \leq$ $0.05)$

Again, when analyzing the results of the soluble protein and carbohydrate contents, it was observed that MW 200 had the lowest value among the substrates containing MW and exhibited linearity of the results of these solutes in the treatments containing SW.

\section{Discussion}

\subsection{Plant Growth and Number of the Fruits}

In the three parameters analyzed (shoot height, stem diameter and number of leaves), a positive effect of the residues on the growth of $C$. chinense Jacq. plants was observed at all concentrations tested compared to plants growing under control conditions. Linearity of the results of the two residues was also observed: a higher concentration of residues in substrates increased plant growth almost linearly.

When applied properly, organic residues have the ability to improve physical, chemical and biological properties of the soil. Some of the effects of these residues in the soil include the following: an increase in concentration of organic matter and capacity of cation exchange; an increase of $\mathrm{pH}$ (acid soil correction); an improvement in soil structure, making the soil more stable and favoring better aeration and permeability; and an increase in water 
retention capacity and higher nutritional quality by making available nutrients such as nitrogen, phosphorus, sulfur and micronutrients (Abreu-Júnior et al., 2005, Aprile \& Lorandi, 2012; Bot \& Benites, 2005; Cardoso et al., 2013). These benefits mean better cultivation conditions, exerting a positive effect on plant growth and development and providing higher productivity and quality of agricultural products (Abreu-Júnior et al., 2005; Bot \& Benites, 2005; Nardi, Pizzeghello, Muscolo, \& Vianello, 2002).

The pepper plant growth results found in this study are in agreement with those found by several authors and confirm the benefits of using organic solid waste properly treated in plant cultivation. N. Tzortzakis et al. (2012) studied the performance and suitability of municipal solid waste compost (MSWC) in different content and/or fertigation in pepper (Capsicum annuит L.) plants growing under in greenhouse conditions. The addition of MSWC into the soil increased nutritive value (N, K, P, organic matter) resulting in increased EC (electrical conductivity). The results indicated the low content of MSWC added into substrate improved plant growth and maintained fruit fresh weight without affecting plant yield, while fertigation acted beneficially.

F. J. F. Araújo, M. D. Aquino, B. F. Aquino, F. M. L. Bezerra and F. Chagas-Neto (2009) prepared an organic flour from crab waste and used it in different proportions in substrate composition used in the production of cowpea beans (Vigna unguiculata [L.] Walp). The substrates analyzed were formed from local soil mixed with different concentrations of chemical fertilizer and/or crab organic flour. Chemical analyses indicate excellent results of this organic product, highlighting the contents of nitrogen, phosphorus, magnesium, calcium and organic matter. The great agronomic potential of the crab waste flour was confirmed by good performance of the plants grown on substrates containing crab fertilizer, providing in some treatments a reduction in the need for chemical fertilizer applications.

A. Chrysargyris, C. Saridakis and N. Tzortzakis (2013) evaluated substrates with different contents of municipal solid waste (MSW) and/or peat in the cultivation of melon (Citrulus melo L.) seedlings growing under in greenhouse conditions. The results showed that the high content of MSW affected negatively plant growth, but the low content of MSW may act as an alternative substitute of peat in melon seedling production.

Fachini, Galbiatti and Pavani (2004) studied the effects of substrates with different proportions of pine bark and organic waste compounds in the formation of orange seedlings and found that the mixture of $60 \%$ pine bark and $40 \%$ municipal waste compound provided better and faster plant development, outside of supplying nutrients, very effective.

High concentrations of nitrogen promote intense plant growth, especially favoring leaf development and, consequently, green mass production. However, in some plants, excess nitrogen can harm fruit production (Keller, 2005; C. M. F. Pinto, P. C. Lima, L. T. Salgado, \& F. L. B. Caliman, 2006). This fact was clearly observed in treatments that used shrimp waste. The SW 200 treatment greatly increased plant growth, more than all other treatments. However, the SW 200 treatment did not improve fruit production, possibly due to excess nitrogen.

Considering the results obtained from plant growth and fruit production and also the importance of proper disposal of the largest possible amount of MW and SW, the use of these residues can be indicated for the production of $C$. chinense Jacq. peppers. In this study, the most recommended treatments would be MW 200 and SW 100 or SW 200, depending on the purpose. The SW 200 treatment would be indicated if the greatest interest was green mass production for fodder, and SW 100 would be indicated if the interest mostly involved fruit production.

\subsection{Enzymatic Activity}

The high activity of antioxidant enzymes can contribute to greater postharvest life. Masia (1998) observed that Golden Delicious apples had a higher activity of superoxide dismutase (SOD) and CAT at harvest compared to Fuji apples, resulting in a longer cold storage period of Golden Delicious apples. Similarly, Lacan and Baccou (1998) verified that Clipper melons showed an increase in the activities of SOD and CAT compared to those of Jerac melons. As a result, Clipper melons had greater postharvest life. Moreover, Y. S. Wang, S. P. Tian and Y. $\mathrm{Xu}$ (2005) developed a research with peach fruits (Amygdalus persica cv. Okubo) and found that the decrease of SOD and CAT might contribute to the development of chilling injury in the fruits.

Maciel (2012) studied acerola fruits of six clones stored at temperatures of $4{ }^{\circ} \mathrm{C}$ and $8{ }^{\circ} \mathrm{C}$ (minimum temperature of safety for the acerola) for up to 12 days. The author observed that in the fruits stored at $4{ }^{\circ} \mathrm{C}$, the activities of enzymes were higher than those of fruits stored at $8{ }^{\circ} \mathrm{C}$. This may have been responsible for protection against oxidative stress generated by the cold at $4{ }^{\circ} \mathrm{C}$, maintaining the quality of the fruit.

Several studies demonstrate the induction of an antioxidant enzymatic system as a strategy to increase the 
tolerance of fruits to cold and thus prolong their shelf lives. Sestari (2010) observed a reduction in the sensitivity of Nanicão bananas when immersed in water at $42{ }^{\circ} \mathrm{C}$ for $15 \mathrm{~min}$ or at $53{ }^{\circ} \mathrm{C}$ for $2 \mathrm{~min}$ prior to storage at $6{ }^{\circ} \mathrm{C}$ for up to 15 days. According to the author, the low temperature intensified the generation of ROS in fruits, but the heat treatments improved the antioxidant enzymatic system, reducing oxidative stress and resulting in lower rates of injuries in these fruits.

Kluge et al. (2006) found that intermittent warming $\left(6\right.$ days at $1{ }^{\circ} \mathrm{C}+1$ day at $\left.25^{\circ} \mathrm{C}\right)$ in Valência orange, Tahiti lime and Murcott tangor stored at $1{ }^{\circ} \mathrm{C}$ reduced injuries caused by cold. Biochemical analyses revealed greater activity or peaks in CAT, APX and glutathione reductase enzymes during the storage period in the fruits of the treatment. These results may be related to increased resistance of the fruits to cold.

In the present study, in general, the treatments with residues provided an increase in CAT activity in pepper fruits; however, the peroxidases (APX and GPX) had their activities reduced. Despite this, it is possible that these results can contribute to greater postharvest life of $C$. chinense Jacq. pepper fruits. CAT is one of the most important enzymes in the process of elimination of hydrogen peroxide, avoiding the formation of the hydroxyl radical and consequent cellular damage (Sies, 1993; Vaidyanathan, Pattathil, Chakrabarty, \& Thomas, 2003). Maciel (2012), Sestari (2010) and Kluge et al. (2006) found in their experiments that CAT was the main enzyme involved in the removal of hydrogen peroxide in fruits.

According to Valderrama and Clemente (2004), peroxidase is one of the main enzymes responsible for the deterioration of quality in many fruits. The removal of hydrogen peroxide by this enzyme occurs concomitantly with the oxidation of phenolic compounds to quinones, which rapidly polymerize, forming melanin and pigments of dark color. The enzymatic browning reduces the quality of fruits and their nutritional characteristics (M. I. F. Chitarra \& A. B. Chitarra, 2005; Fennema, 2010; Lurie, 2003; Márques, Fleuriet, \& Macheix, 1995). The activities of peroxidase are still related to loss of flavor, texture and fruit nutrients (Barrett, Beaulieu, \& Shewfelt, 2010; Hui, 2006). Thus, although this enzyme performs an important role in the elimination of hydrogen peroxide, the control of its activities is desirable because it can contribute to the conservation of fruit quality (M. I. F. Chitarra \& A. B. Chitarra, 2005; Sousa, 2010). In this study, residues reduced the activity of peroxidase.

In this context, the MW 100 and SW 200 treatments would provide greater shelf life of fruits. However, considering also the growth and production of pepper fruits, the most suitable treatments would be MW 100 and SW 100.

\subsection{Organic Solutes}

The SW 200 treatment showed the highest results in relation to protein content, elevating the content of this solute in the fruits. The nutritional significance of peppers is due in part to the presence of large amounts of protein in fruits (P. Vaishnava \& D. W. Wang, 2003). In plants, proteins are involved in the processes of maturation, germination, cell death, response to oxidative stress processes and others (Bouteau \& Bailly, 2008; S. L. T. Lima et al., 2008; Wojtyla, Lechowska, Kubala, \& Garnczarska, 2016).

The residues did not increase the soluble carbohydrate content at any concentration, but in MW 100 and SW 200, these solutes were not reduced. The soluble sugars represent a large part of the total soluble solids (TSS), one of the variables that affects directly the quality of the fruit. Plant development conditions, such as fertilization, irrigation and temperature, influence the carbohydrate content in fruits (Razek et al., 2011; Germano, 2000; Hobson \& Grierson, 1993; Whiting, 1970; Yahia, 2011). Sacramento, Matos, Souza, Barretto and Faria (2007) related that high contents of TSS are important for the consumption of fresh fruit and for industry because the high contents provide better taste and higher yield in the preparation of the products.

In relation to nutritional quality, the treatments with residues that produced the best results were MW 100 and SW 200. However, in general, the treatments that showed better results considering all parameters analysed were MW 100 and SW 100, although SW 100 provided a reduction in the nutritional quality of fruit.

\section{Conclusions}

The MW and SW at all concentrations analyzed provided an increase in the parameters of shoot height, stem diameter and number of leaves in $C$. chinense Jacq. plants. The results for both residues were linear such that the greatest plant growth occurred in treatments with higher concentrations of these residues (MW 200 and SW 200).

The numbers of fruits of the treatments were quite variable. However, it can be concluded that the MW 200 and SW 100 treatments provided the highest fruit production. 
The best results for the activities of CAT, APX and GPX occurred in the MW 100 and SW 200 treatments. Both provided an increase in CAT and a reduction in APX and GPX, which can contribute to greater postharvest life of the $C$. chinense Jacq. fruits.

The use of MW and SW in nutritional recommendations for cultivation (MW 100 and SW 100) did not contribute to an increase in soluble protein and carbohydrate contents. In the other residue concentrations, the results were quite variable. Thus, it was not possible to establish a precise relationship between application of waste and improvement in the nutritional quality of the fruit.

Thus, considering all parameters analyzed, the most suitable treatments would be MW 100 and SW 100 . Therefore, the most suitable treatments indicated are in accordance with the recommendation suggested by the EMBRAPA based on the amount of nitrogen used in the cultivation of pepper. Moreover, the results demonstrate the susceptibility of using substrates with MW and SW in the cultivation of $C$. chinense Jacq. plants.

\section{Acknowledgements}

We thank Proof-Reading-Service.com for language corrections.

\section{References}

Abreu-Júnior, C. H., Boaretto, A. E., Muraoka, T., \& Kiehl, J. C. (2005). Uso agrícola de resíduos orgânicos potencialmente poluentes: propriedades químicas do solo e produção vegetal. Tópicos Especiais em Ciência do Solo, 4, 391-470. Retrieved from

http://www.scielo.br/scielo.php?script=sci_nlinks\&ref=000080\&pid=S1415-4366200700010001400001\&ln $\mathrm{g}=\mathrm{pt}$

Amaro, G. B. (2012). Capsicum chinense. Empresa Brasileira de Pesquisa Agropecuária. Retrieved from https://www.agencia.cnptia.embrapa.br/gestor/pimenta/arvore/CONT000gn0frh1202wx5ok0liq1mqt5bf5ht. html

Aprile, F., \& Lorandi, R. (2012). Evaluation of Cation Exchange Capacity (CEC) in Tropical Soils using four different Analytical Methods. Journal of Agricultural Science, 4, 278-289. http://dx.doi.org/10.5539/jas.v4n6p278

Araújo, F. J. F., Aquino, M. D., Aquino, B. F., Bezerra, F. M. L., \& Chagas-Neto, F. (2009). Aplicação do composto orgânico produzido a partir de caranguejo uçá Ucides cordatus cordatus no cultivo de feijão caupi Vigna unguiculata (L.) WALP. Engenharia Ambiental, 6, 15-35. Retrieved from http://ferramentas.unipinhal.edu.br/engenhariaambiental/include/getdoc.php?id=952\&article=276\& mode $=$ p df.

Barrett, D. M., Beaulieu, J. C., \& Shewfelt, R. (2010). Color, flavor, texture, and nutritional quality of fresh-cut fruits and vegetables: desirable levels, instrumental and sensory measurement, and the effects of processing. Critical Reviews in Food Science and Nutrition, 50, 369-389. http://dx.doi.org/ 10.1080/10408391003626322

Bot, A., \& Benites, J. (2005). The importance of soil organic matter: key to drought-resistant soil and sustained food production. Rome: Food and Agriculture Organization of the United Nations.

Bouteau, H. E. M., \& Bailly, C. (2008). Oxidative signaling in seed germination and dormancy. Plant Signaling \& Behavior, 3, 175-182. Retrieved from https://www.ncbi.nlm.nih.gov/pmc/articles/PMC2634111/

Bradford, M. M. (1976). A rapid and sensitive method for the quantification of microgram quantities of protein utilizing the principle of protein-dye binding. Analytical Biochemistry, 72, 246-254. http://dx.doi.org/10.1016/0003-2697(76)90527-3

Cardoso, E. J. B. N., Vasconcellos, R. L. F., Bini, D., Miyauchi, M. Y. H., Santos, C. A., Alves, P. R. L., ... Nogueira, M. A. (2013). Soil health: looking for suitable indicators. What should be considered to assess the effects of use and management on soil health? Scientia Agricola, 70, 274-289. http://dx.doi.org/10.1590/S0103-90162013000400009

Chitarra, M. I. F., \& Chitarra, A. B. (2005). Pós-colheita de frutas e hortaliças: fisiologia e manuseio. Lavras: UFLA.

Chrysargyris, A., Saridakis, C., \& Tzortzakis, N. (2013). Use of municipal solid waste compost as growing medium component for melon seedlings production. Journal of Plant Biology \& Soil Health, 2, 1-5. Retrieved from

https://www.researchgate.net/publication/288823666_Use_of_municipal_solid_waste_compost_as_growing 
_medium_component_for_melon_seedlings_production

Dubois, M., Gilles, K. A., Hamilton, J. K., Rebers, P. A., \& Smith, F. (1956). Colorimetric method for determination of sugars and related substances. Analytical Chemistry, 28, 350-356. http://dx.doi.org/10.1021/ac60111a017

EMBRAPA. (2007). Pimenta (Capsicum spp.). Empresa Brasileira de Pesquisa Agropecuária. Retrieved from http://sistemasdeproducao.cnptia.embrapa.br/FontesHTML/Pimenta/Pimenta_capsicum_spp/adubacao.html

Fachini, E., Galbiatti, J. A., \& Pavani, L. C. (2004). Níveis de irrigação e de composto de lixo orgânico na formação de mudas cítricas em casa de vegetação. Engenharia Agrícola, 24, 578-588. http://dx.doi.org/10.1590/S0100-69162004000300010

Fennema, O. R. (2010). Química de los alimentos (3rd ed.). Zaragoza: Acribia.

Germano, S. (2000). Desenvolvimento de bioprocessos para a produção, caracterização e purificação de proteases de Penicillium sp. por fermentação no estado sólido (Unpublished doctoral dissertation). Universidade Federal do Paraná, Paraná, Brazil.

Havir, E., \& McHale, N. A. (1987). Biochemical and developmental characterization of multiple forms of catalases in tobacco leaves. Plant Physiology, 84, 450-455. Retrieved from http://www.ncbi.nlm.nih.gov/pubmed/16665461

Hawlliwell, B., \& Gutteridge, J. M. C. (2007). Free radicals in biology and medicine (4th ed.). Oxford: Oxford University Press.

Hobson, G. E., \& Grierson, D. (1993). Tomato. In G. B. Seymour, J. E. Taylor, \& G. A. Tucker (Eds.), Biochemistry of fruits ripening (pp. 405-442). London: Champman \& Hall.

Hui, Y. H. (2006). Handbook of Food Science, Technology, and Engineering (Vol. 2). Boca Raton, FL: CRC Press.

Jacobi, P. R., \& Besen, G. R. (2011). Solid Waste Management in São Paulo: The challenges of sustainability. Estudos Avançados, 25, 135-158. http://dx.doi.org/10.1590/S0103-40142011000100010

Kar, M., \& Mishra, D. (1976). Catalase, peroxidase, and polyphenoloxidase activities during rice leaf senescence. Plant Physiology, 57, 315-319. Retrieved from http://www.ncbi.nlm.nih.gov/pmc/articles/PMC542015/

Keller, M. (2005). Nitrogen - friend or foe of wine quality? Practical Winery \& Vineyard, 27, 24-29. Retrieved from http://www.practicalwinery.com/SeptOct05/septoct05p24.htm

Kluge, R. A., Azevedo, R. A., Jomori, M. L. L., Edagi, F. K., Jacomino, A. P., Gaziola, S. A., \& Aguila, J. S. (2006). Efeitos de tratamentos térmicos aplicados sobre frutas cítricas armazenadas sob refrigeração. Ciência Rural, 36, 1388-1396. Retrieved from http://www.scielo.br/pdf/cr/v36n5/a07v36n5.pdf

Lacan, D., \& Baccou, J. C. (1998). High levels of antioxidant enzymes correlate with delayed senescence in nonnetted muskmelon fruits. Planta, 204, 377-382. http://dx.doi.org/ 10.1007/s004250050269

Lima, S. L. T., Jesus, M. B., Sousa, R. R. R., Okamoto, A. K., Lima, R., \& Fraceto, L. F. (2008). Estudo da Atividade Proteolítica de Enzimas Presentes em Frutos. Química na Escola, 2, 47-49. Retrieved from http://qnesc.sbq.org.br/online/qnesc28/11-EEQ-6906.pdf

Lurie, S. (2003). Antioxidants. In D. M. Hodges (Eds.), Postharvest oxidativestress in horticultural crops (pp. 138-139). New York: Food Products Press.

Maathuis, F. J., \& Diatloff, E. (2013). Roles and functions of plant mineral nutrients. In: F. J. Maathuis (Ed.), Plant mineral nutrients: methods and protocols (pp. 1-21). New York: Humana Press.

Maciel, V. T. (2012). Qualidade e metabolismo antioxidante em frutos de clones de aceroleira armazenados a $4^{\circ}$ e $8^{\circ} \mathrm{C}$ (Unpublished doctoral dissertation). Universidade Federal do Ceará, Ceará, Brazil.

Márques, L., Fleuriet, A., \& Macheix, J. J. (1995). Fruit polyphenol oxidase. New data on and old problem. In C. Y. Lee \& J. R. Whitaker (Eds.), Enzymatic browning and its prevention (pp. 90-102). Washington: American Chemical Society.

Masia, A. (1998). Superoxide dismutase and catalase activities in apple fruit during ripening and postharvest and with special reference to ethylene. Physiologia Plantarum, 104, 668-672.

http://dx.doi.org/ 10.1034/j.1399-3054.1998.1040421.x

MMA. (2012). Plano Nacional de resíduos Sólidos - Versão pós Audiências e Consulta Pública para Conselhos Nacionais. Brasília. Ministério do Meio Ambiente. Retrieved from 
http://www.mma.gov.br/port/conama/reuniao/dir1529/PNRS_consultaspublicas.pdf

Møller, I. M., Jensen, P. E., \& Hansson, A. (2007). Oxidative modifications to cellular components in plants. Annual Review of Plant Biology, 58, 459-481. http://dx.doi.org/ 10.1146/annurev.arplant.58.032806.103946

Nakano, Y., \& Asada, K., 1981. Hydrogen peroxide is scavenged by ascorbate-specific peroxidase in spinash chloroplasts. Plant and Cell Physiology, 22, 867-880.

Retrieved from http://pcp.oxfordjournals.org/content/22/5/867.short?rss=1\&ssource=mfc

Nardi, S., Pizzeghello, D., Muscolo, A., \& Vianello, A. (2002). Physiological effects of humic substances on higher plants. Soil Biology \& Biochemistry, 34, 1527-1536. http://dx.doi.org/ 10.1016/s0038-0717(02)00174-8

Noctor, G., \& Foyer, C. H. (1998). Ascorbate and glutathione: keeping active oxygen under control. Annual Review of Plant Physiology and Plant Molecular Biology, 49, 249-279. http://dx.doi.org/10.1146/annurev.arplant.49.1.249

Pinto, C. M. F., Lima, P. C., Salgado, L. T., \& Caliman, F. L. B. (2006). Nutrição Mineral e adubação para pimenta. Informe Agropecuário, 27, 50-57. Retrieved from www.epamig.br/index.php?option=com_docman\&task=doc...

Ramakrishna, A., \& Ravishankar, G. A. (2011). Influence of abiotic stress signals on secondary metabolites in plants. Plant Signaling \& Behavior, 6, 1720-1731. http://dx.doi.org/ 10.4161/psb.6.11.17613

Razek, A. E., Treutter, D., Saleh, M. M. S., Shammaa, M. E., Amera, A. F., \& Hamid, N. A. (2011). Effect of nitrogen and potassium fertilization on productivity and fruit quality of 'crimson seedless' grape. Agriculture and Biology Journal of North America, 2, 330-340. Retrieved from https://www.researchgate.net/publication/215456877_Effect_of_nitrogen_and_potassium_fertilization_on_ productivity_and_fruit_quality_of_'Crimson_seedless'_grape

Rocha, I. P. (2011). Carcinicultura brasileira: processos tecnológicos, impactos socioeconômicos, sustentabilidade ambiental, entraves e oportunidades. Revista da ABCC, 13, 36-34. Retrieved from http://abccam.com.br/site/wp-content/uploads/2011/03/carcinicultura\%20brasileira\%20-\%20revista\%20abc c\%20-\%20janeiro\%202011.pdf

Sacramento, C. K., Matos, C. B., Souza, C. N., Barretto, W. S., \& Faria, J. C. (2007). Características físicas, físico-químicas e químicas de cajás oriundos de diversos municípios da região sul da Bahia. Magistra, 19, 283-289. http://dx.doi.org/10.1590/1807-1929/agriambi.v18n08p856-860

Sestari, I. (2010). Indução de tolerância de frutos às injúrias de frio: aspectos fisiológicos e bioquímicos (Unpublished doctoral dissertation). Universidade de São Paulo, São Paulo, Brazil.

Sies, H. (1993). Strategies of antioxidante defense. European journal of biochemistry, 215, 213-219. http://dx.doi.org/ 10.1111/j.1432-1033.1993.tb18025.x

Smith, P. G., \& Heiser, C. B. (1957). Taxonomy of Capsicum chinense Jacq. and the geographic distribution of the cultivated Capsicum species. Bulletim of the Torrey Botanical Club, 84, 413-420. http://dx.doi.org/10.2307/2482971

Sousa, T. P. A. (2010). Caracterização parcial da peroxidase dos frutos de aceroleira (Malphigia emarginta DC), clones Okinawa e Emepa em três estágios de maturação (Unpublished master's thesis). Universidade federal da Paraíba, Paraíba, Brazil.

Tzortzakis, N., Gouma, S., Dagianta, E., Saridakis, C., Papamichalaki, M., Goumas, D., \& Manios, T. (2012). Use of Fertigation and Municipal Solid Waste Compost for Greenhouse Pepper Cultivation. The Scientific World Journal, 1-8. http://dx.doi.org/10.1100/2012/973193

Vaidyanathan, H., Pattathil, S., Chakrabarty, R., \& Thomas, G. (2003). Scavenging of reactive oxygen species in $\mathrm{NaCl}$-stressed rice (Oryza sativa L.) - differential response in salttolerant and sensitive varieties. Plant Science, 165, 1411-1418. http://dx.doi.org/ http://dx.doi.org/10.1016/j.plantsci.2003.08.005

Vaishnava, P., \& Wang, D. H. (2003). Capsaicin sensitive-sensory nerves and blood pressure regulation. Current Medicinal Chemistry-Cardiovascular \& Hematological Agents, 1, 177-188. http://dx.doi.org/10.2174/1568016033477540.

Valderrama, P., \& Clemente, E. (2004). Isolation and thermostability of peroxidase isoenzymes from apple cultivars Gala and Fugi. Food Chemistry, 87, 601-606. http://dx.doi.org/ 10.1016/j.foodchem.2004.01.014 
Wang, Y. S., Tian, S. P., \& Xu, Y. (2005). Effects of high oxygen concentration on pro- and anti-oxidant enzymes in peach fruits during postharvest periods. Food Chemistry, 91, 99-104. http://dx.doi.org/10.1016/j.foodchem.2004.05.053

Whiting, G. C. (1970). Sugars. In A. C. Hulme (Eds.), The biochemistry of fruit and their products (pp. 1-31). London: Academic Press.

Wojtyla, Ł., Lechowska, K., Kubala, S., \& Garnczarska, M. (2016). Different Modes of Hydrogen Peroxide Action during Seed Germination. Frontiers in Plant Science, 7, 66. http://dx.doi.org/10.3389/fpls.2016.00066

Worrell, W. A., \& Vesilind, P.A. (2012). Solid Waste Engineering (2nd ed.). Stamford: Cengage Learning.

Yahia, E. M. (2011). Postharvest Biology and Technology of Tropical and Subtropical Fruits: Volume 3 Cocona to Mango. Cambridge: Woodhead Publishing.

\section{Copyrights}

Copyright for this article is retained by the author(s), with first publication rights granted to the journal.

This is an open-access article distributed under the terms and conditions of the Creative Commons Attribution license (http://creativecommons.org/licenses/by/4.0/). 